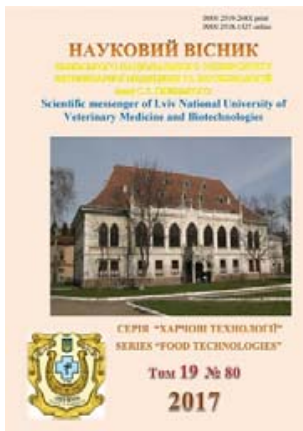

Науковий вісник Львівського національного університету ветеринарної медицини та біотехнологій імені С.З. Гжицького

Scientific Messenger of Lviv National University of Veterinary Medicine and Biotechnologies

doi:10.15421/nvlvet8012

ISSN 2519-268X print

ISSN 2518-1327 online

http://nvlvet.com.ua/

УДК 637.146:636.292

\title{
Використання кріопорошку «Амарант» в технології молочних продуктів лікувально-профілактичного спрямування
}

\author{
Ю.Р. Гачак, Б.В. Гутий, А. Беницька, Т. Дякун, Р. Пристанський, Л. Кінницька, В.Р. Сельський \\ hachakyuriy@gmail.com
}

Львівський національний університет ветеринарної медицини та біотехнологій імені С.3. Гжицького, вул. Пекарська, 50, Львів, 79010, Україна

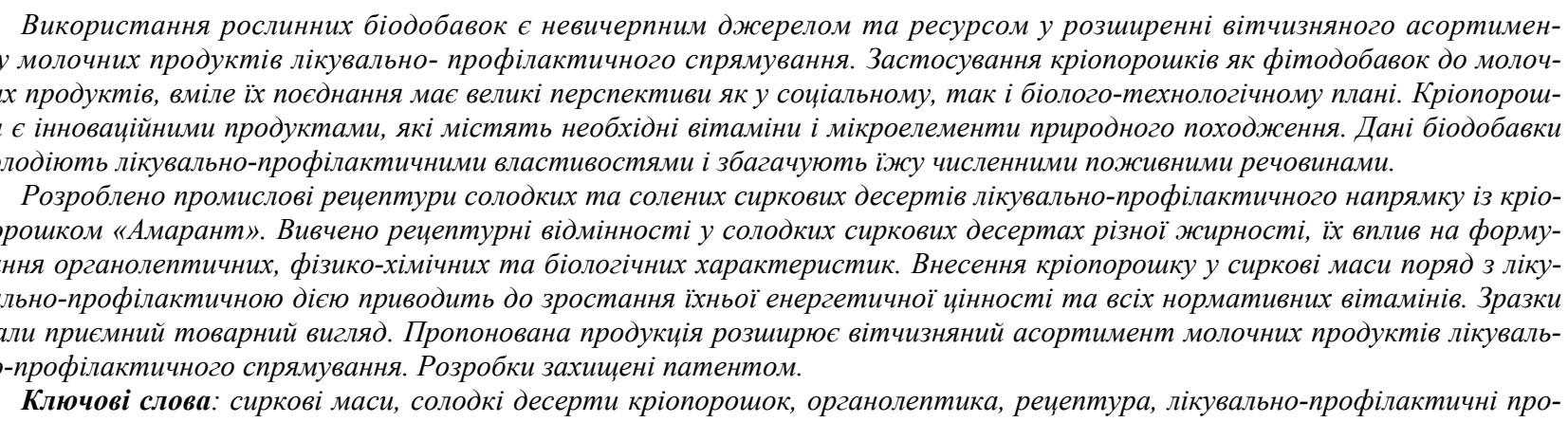
дукти, біологічна циінність.

\section{Использование криопорошку «Амарант» в технологии молочных продуктов лечебно-профилактического направления}

\author{
Ю.Р. Гачак, Б.В. Гутый, А. Беницка, Т. Дякун, Р. Пристанский, Л. Кинницкая, В.Р. Сельський \\ hachakyuriy@gmail.com
}

Львовский национальный университет ветеринарной медицины и биотехнологий имени С.3. Гжиџкого, ул. Пекарская, 50, г. Львов, 79010, Украина

\begin{abstract}
Использование растительных биодобавок является неисчерпаемым источником и ресурсом в расширении отечественного ассортимента молочных продуктов лечебно-профилактического направления. Применение криопорошков как фитодобавок к молочным продуктам, умелое их сочетание имеет большие перспективы, как в социальном, так и биологотехнологическом плане. Криопорошки являются инновационными продуктами, которые содержат необходимые витамины и микроэлементы естественного происхождения. Данные биодобавки обладают лечебно-профилактическими свойствами и обогащают пищу многочисленными питательными веществами.

Разработаны промылиленные рецептуры сладких и соленых творожных десертов лечебно-профилактического направления с криопорошком «Амарант». Изучено рецептурные различия в сладких творожных десертах различной жирности, их влияние на формирование органолептических, физико-химических и биологических характеристик. Внесение криопорошка в творожные массы наряду с лечебно-профилактическим действием приводит к росту их энергетической ценности и всех нормативных витаминов. Образиы имели приятный товарный вид. Предлагаемая продукиия расширяет отечественный ассортимент молочных продуктов лечебно-профилактического направления. Разработки защищены патентом.
\end{abstract}

Citation:

Gachak, Yu.R., Gutyj, B.V., Benitska, A., Dyakun, T., Pristantsky, R., Kinitska, L., Selskyi, V. (2017). Use of «Amarant» cryoproush in the technology of dairy products of treatment and propofilactic degradation. Scientific Messenger LNUVMB, 19(80), 57-62. 
Ключевые слова: творожные массы, сладкие десерты криопорошок, органолептика, рецептура, лечебнопрофилактические продукты, биологическая ценность.

\title{
Use of «Amarant» cryoproush in the technology of dairy products of treatment and propofilactic degradation
}

\author{
Yu.R. Gachak, B.V. Gutyj, A. Benitska, T. Dyakun, R. Pristantsky, L. Kinitska, V.R. Selskyi \\ Stepan Gzhytskyi National University of Veterinary Medicine and Biotechnologies Lviv, \\ Pekarska Str., 50, Lviv, 79010, Ukraine
}

\begin{abstract}
The use of plant bio-additives is an inexhaustible source and resource in expanding the domestic range of dairy products for therapeutic and prophylactic purposes. The use of cryopresources, as phytodactyls for dairy products, their combination of strengths has great prospects, both in social and bio-technological terms. Cryopresources are innovative products that contain the necessary vitamins and trace elements of natural origin. These dietary supplements have therapeutic and prophylactic properties and enrich the food with many nutrients.

The industrial formulations of sweet and salty cheese desserts of the treatment and prophylactic direction with cryopowder "Amaranth» were developed. The recipe differences in sweet cheesecake desserts of different fat content, their influence on the formation of organoleptic, physical, chemical and biological characteristics were studied. The introduction of cryopowder in cottage cheese mass along with therapeutic and preventive action leads to an increase in their energy value and all normative vitamins. The samples had a pleasant appearance. The offered products expands the domestic assortment of dairy products of medical and prophylactic direction. Developments are patent protected.

Key words: cheese masses, sweet desserts, cryopowder, organoleptic, recipe, therapeutic and prophylactic products, biological value.
\end{abstract}

\section{Вступ}

У сучасних складних екологічних та економічних умовах питання захисту населення України від несприятливих умов зовнішнього середовища, а саме підвищеного вмісту важких металів, виведення з організму радіонуклідів, забезпечення дефіцитними інгредієнтами, підвищення неспецифічної резистентності до дії несприятливих факторів зовнішнього середовища, сучасна молочна промисловість пов'язує зі створенням продуктів харчування нового покоління. Серед широкого загалу ефективних шляхів захисту населення в умовах складної екологічної обстановки є налагодження підприємствами харчової промисловості виготовлення продуктів лікувальнопрофілактичного призначення, в тому числі молочних. 3 урахуванням сучасний складних екологічних умов існує гостра необхідність в покращенні структури харчування населення за рахунок підвищення якості, біологічної цінності та смакових характеристик продуктів. Важливим напрямком у цьому відношенні $\epsilon$ збагачення їх вітамінами, мінеральними та імунними речовинами, особливо на натуральній основі (Hachak et al., 2011; Yatsenko et al., 2016; Gutyj et al., 2017).

Останнім часом значно розширився асортимент продуктів харчування, збагачених окремими функціональними інгредієнтами, такими, як вітаміни, мінеральні речовини, харчові волокна, пробіотичні мікроорганізми і т. д. Не є винятком в цьому напрямку і молочні продукти. Згідно з літературними повідомленнями велика увага приділяється молочним продуктам, що володіють високою харчовою цінністю, збагаченими вітамінами і мінеральними речовинами за рахунок введення функціональних інгредієнтів, однією 3 вимог, що висуваються до останніх, $\epsilon$ їх натуральність. На нашу думку, перспективним, цікавим на- прямком є використання рослинних біодобавок вітчизняного виробництва. Яскравими представниками серед них є вітчизняні біодобавки - кріопорошки із зазначеними, чітко визначеними функціями.

Використання кріопорошку «Амарант» у технології таких популярних продуктів, як сиркові десерти, не лише розширює асортимент молочних лікувальнопрофілактичних продуктів, а й зміцнювтиме імунітет людей.

У зв'язку 3 цим нами були запропоновані дослідження щодо можливості використання нової вітчизняної кріодобавки як рецептурного складника в технології солодких десертів різної жирності.

\section{Матеріал і методи досліджень}

Дослідження проводились в умовах наукової лабораторії кафедри технології молока і молочних продуктів Львівського національного університету ветеринарної медицини та біотехнології імені C.3. Гжицького, а також в умовах ТзОВ «Прометей» («Львівський молококомбінат»).

Метою роботи була розробка технології нових солодких сиркових мас із кріопорошком «Амарант». 3 цією метою детально вивчали можливість використання пропонованого кріопорошку в технології даної молочної продукції, технологічні можливості застосування кріопорошку, доцільність попередньої підготовки та пошук необхідних співвідношень при додаванні до молочної основи. Як молочну основу відібрано два види сиру (нежирний та з 5\% жирності), а як лікувально-профілактичну біодобавку використано кріопорошок «Амарант».

Кріопорошок «Амарант» - нова вітчизняна фітодобавка із численними унікальними властивостями. Зерно амаранту містить до 16\% білка (що складається більш ніж на $30 \% 3$ незамінних амінокислот), 
близько 9-11\% харчових волокон (клітковини). У складі амарантового насіння також вельми високий вміст вітамінів (E, A, $\mathrm{B}_{1}, \mathrm{~B}_{2}, \mathrm{~B}_{4}$ (холін), C, D), дуже важливих для організму людини макро- і мікроелементів (Залізо, Калій, Кальцій, Фосфор, Магній, Мідь і ін.), а також інших біологічно активних речовин, що визначають різноманітні лікувально-профілактичні властивості амарантового борошна (сквален, фітостероли, фосфоліпіди та ін.).

В практично ідеально збалансованому білковому складі амарантового борошна, що відрізняється високим вмістом незамінних амінокислот, провідні місця займають необхідні для нормального функціонування людського організму амінокислоти лізин, метіонін і триптофан.

У амарантовому борошні також досить висока концентрація холіну. Ця речовина входить до складу лецитину, який є структурним компонентом нервових волокон і клітин мозку. Холін позитивно впливає на роботу центральної і периферичної нервової систем, покращує пам'ять і розумові здібності людини, сприяє зниженню рівня холестерину в крові, а також бере участь в природному синтезі фосфоліпідів, що запобігають жировому гепатозу печінки.

Склад амінокислот амаранту ідеально збалансований. За збалансованості амінокислотного складу замінних і незамінних амінокислот білок амаранту при- рівнюється до білка жіночого молока. А вміст найважливішої незамінної амінокислоти - лізину в 30 разів вищий, ніж у пшениці. У такій кількості цієї амінокислоти немає більше ні в одній з вивчених рослин! При нестачі лізину іжа просто не засвоюється і білок «проходить» організм транзитом.

Особлива цінність амаранту полягає у наявності в його складі такої речовини, як сквален, що володіє сильною антиоксидантною дією, рекомендується при атеросклерозі та ішемічній хворобі серця, знижує рівень холестерину, сприяє зменшенню ризику серцево-судинних i онкологічних захворювань, значно зміцнює імунну систему, сприяє виведенню шлаків, радіонуклідів і солей важких металів з організму.

Дози пропонованої фітодобавки розроблялись на основі рекомендованих добових норм споживання плавленого сиру для різних вікових груп, лікувальнопрофілактичних доз біодобавки.

Експериментальна серія досліджень включала в себе пошук та виявлення оптимальних співвідношень «молочних основ» різної жирності та кріо- біодобавки, дослідження їх органолептичних, технологічних та лабораторних показників, оцінку їх біологічної та харчової цінності даних сиркових виробів. Згідно 3 проведеними попередніми дослідженнями відбирались оптимальні кількості, в яких і проводились вищенаведені дослідження.

Схема

\section{Технологічна схема виготовлення солодких сиркових мас із кріодобавкою}

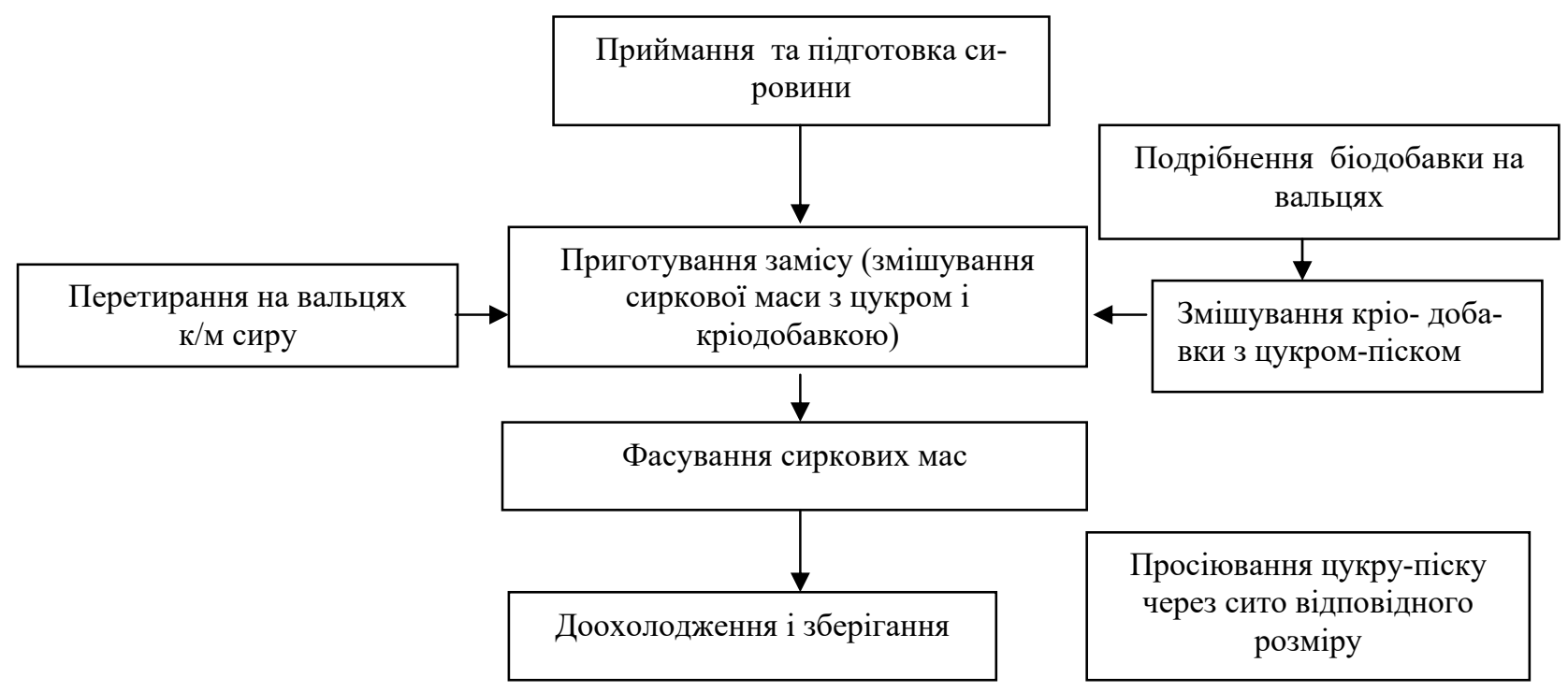

Визначальним фактором при додаванні біодобавок було збереження (максимально можливе наближення) нормативних характеристик солодких сиркових виробів. Дози препаратів задавались та розраховувались, виходячи з їх профілактично-лікувальних доз препаратів на 100-150 г сиркової маси. Рецептура сирних мас перераховувалась для промислового виробництва (з розрахунку на 1000 кг готового продукту). Рекомендовану біодобавку «Амарант» перед змішуванням 3 цукром, попередньо подрібнюють 3 допомогою вальців. Просіяний цукор змішують з порошком біодобавки. Підготовлені до виробництва усі види сировини, передбачені рецептурою, зважують і приступають до підготовки замісу.

У місильну машину закладають кисломолочний сир відповідної жирності (температура $12 \pm 3{ }^{\circ} \mathrm{C}$ ), включають мішалку і вносять змішаний з пропованою біодобавкою цукровий пісок. Середня тривалість перемішування складає 5-10 хв.

Після закінчення обробки отриману масу охолоджують на охолоджувачах чи у холодильних камерах до температури не вище $4 \pm 2{ }^{\circ} \mathrm{C}$ і фасують. 


\section{Результати та їх обговорення}

Сучасні технології молочних функціональних продуктів насамперед спрямовані на збереження корисних речовин молока, оскільки молоко є природним функціональним продуктом. В наш час стрімко зростає роль наповнювачів при виробництві молочної продукції. Суспільство невпинно вимагає вдосконалення наявних та створення щораз нових технологій продуктів, в тому числі і сиркових десертів. Спектр їхнього використання є дуже широким. У зв'язку із цим використовують наповнювачі як тваринного, так i рослинного походження. Важливе завдання наповнювачів - підвищення біологічної, харчової та технічної якості, а також цінність виготовлюваних продуктів. Це дасть змогу створювати широкий асортимент продукції, яка буде мати властивості базового продукту, наповнювача, який використовується, і результату їх спільної діяльності.

Останнім часом науковці та виробничники порушили питання збагачення молочних продуктів дефіцитними вітамінами та мінеральними речовинами як складовими фітодобавок. Так, при одержані комбінованих масел, м'яких, сичужних сирів запропоновано використовувати різновиди плодово-ягідної сировини, диких та лікарських рослин, морські продукти, продукти бджільництва лікувально-профілактичного призначення.

Останнім часом розроблено молочно-білкові композиції сиркових паст, напоїв, збагачених фітодобавками, вітамінами та мікроелементами, композиціями мікроорганізмів, прянощами (Цісарик О.Й., 2010; Гачак Ю.Р., 2011; Гачак Ю.Р., Панасюк Н., 2012; Мусій Л.Я., Цісарик О.Й., Чоп Р.В., 2013) поживні властивості рослинної біодобавки спіруліни, численних спецій широко використовувались співробітниками кафедри технології молока і молочних продуктів в технології виготовлення сичужних сирів (сир «Комарнівський малюк»), плавлених сирів, солених сиркових мас та сиру «Домашній» різної жирності.

Численними дослідниками розроблено молочнобілкові композиції сиркових паст, напоїв, збагачених фітодобавками (Гачак Ю.Р, Павлюк Н, 2013; Сливка Н. Б., 2015; Гачак Ю. Р., 2015; 2016), у різних агрегатних станах із тривалими термінами зберігання.

У наукових працях почали з'являтись повідомлення про використання у ролі біодобавок і кріопорош-

ків. Так, Пащенко А.О. (2016) запропонував для промислового виробництва рецепти солодких та солених сиркових мас лікувально-профілактичного напрямку із кріопорошком «Гарбуз».

Тицейко Н.I. (2016) розробив для промислового виробництва для промислового виробництва рецептури солених сиркових мас лікувально-профілактичного напрямку iз кріопорошками «Морська капуста» та «Брокколі», i таких прикладів щодо застосування кріопорошків у харчовій галузі щораз більше.

Ці дані дозволяють рекомендувати кріопорошки для використання їх у технологіях виробництва молочних продуктів. Особливої уваги у цьому плані заслуговує новий вітчизняний кріопорошок «Амарант».

Основними критеріями при розробці нами рецептур 2-х видів сиркових мас був пошук оптимальних співвідношень складників 3 метою отримання належних нормативних смакових якостей, що наведені у наступних таблицях.

У таблицях $(1,2,3)$ представлено оптимальні рецептури солодких сиркових мас різної жирності із використання кріопорошку «Амарант» та результати досліджень основних технологічних характеристик дослідних зразків даної продукції.

У таблиці 1 наведено оптимальні рецептури солодких сиркових мас різної жирності із додаванням кріодобавки. Аналіз цифрового матеріалу показує, що із збільшенням жирності вміст пропонованої добавки дещо зростає (з 80,23 до 84,32 кг на 1000 кг готового продукту). Поряд з цим, слід відзначити, що, вміст цукру змінювався обернено пропорційно - із збільшенням жирності його кількість зменшувалась із 109,23 до 63,89 кг (на 1000 кг готового продукту без урахування втрат).

В комплексі загальної оцінки молочної продукції, оцінки іiі потенційним споживачем надзвичайно важливу роль відіграють органолептичні та товарознавчі властивості харчових продуктів, в тому числі і молочних.

Згідно з нормативними документами властивості продуктів харчування визначають ступенем їх дії на споживача. Зовнішній вигляд кисломолочного сиру та сиркових виробів, його консистенція і більш чи менш виражений і сильний аромат збуджують зір, запах людини, діють на смакосприйняття і викликають ті чи інші реакції, що зумовлюють бажання чи небажання вживати його в їжу.

Таблиия 1

Рекомендовані рецептури солодких сиркових мас із кріопорошком

\begin{tabular}{|c|l|c|c|}
\hline \multirow{2}{*}{ № п/п Склад сиркової маси } & \multicolumn{2}{|c|}{ Види рецептур } \\
\cline { 3 - 4 } & & Нежирні з кріопорошком & Напівжирні з кріопорошком \\
\hline 1 & Кисломолочний сир нежирний & 810,37 & -- \\
\hline & Сир к/м 3 мчж 5\% & -- & 851,79 \\
\hline 2 & Кріопорошок & 109,4 & 63,89 \\
\hline 3 & Цукор-пісок & 80,83 & 84,32 \\
\hline 4 & Всього & 1000 & 1000 \\
\hline
\end{tabular}

Лише за допомогою складного комплексу споживач закріплює за продуктом той чи інший рівень органолептичної якості. Оцінка та визначення органолептичних якостей сиру є основним фактором для встановлення рівня цін на кожен продукт, дозволяючи виявляти, а потім і ліквідувати можливі недоліки при їх виготовлені. Як відомо, повноцінна оцінка органолептичної якості сиру забезпечується за рахунок використання прямих чи непрямих методів вимірювань за допомогою приладів; як прямі методи може бути 
використані вимірювання харчових консистенцій чи аналіз складових елементів, що відповідають за формування аромату сиру.

Органолептичні показники солодких сиркових мас iз використанням кріопорошку «Амарант» наведені у таблиці 2.

Аналіз органолептичних характеристик сиркових мас із кріобіодобавкою показує, що вони зазнали пев- них змін, однак в основному відповідали нормативним вимогам. Так, колір даних сиркових мас був світло-жовтий для та світло-коричневий $з$ численними коричневими вкрапленнями подрібненої порошкоподібної кріобіодобавки. Консистенція дослідних зразків була однорідною, ніжною. Запах сиркових мас залишився чистим, кисломолочним із легким присмаком пропонованої кріодобавки.

Органолептичні показники солодких сиркових мас із кріопорошком «Амарант»

\begin{tabular}{|c|c|c|c|}
\hline Назва сиркової маси & Колір, зовнішній вигляд & Запах і смак & Консистенція \\
\hline $\begin{array}{l}\text { Сиркові маси } 3 \text { напов- } \\
\text { нювачами (ТУ; ТІ) }\end{array}$ & $\begin{array}{lr}\text { Білий } 3 \text { відтінком чи ко- } \\
\text { льором } \\
\text { рівномірний по всій масі }\end{array}$ & $\begin{array}{l}\text { Чистий, кисломолочний, iз } \\
\text { запахом, смаком і ароматом } \\
\text { наповнювача }\end{array}$ & $\begin{array}{l}\text { Однорідна, ніжна, в міру } \\
\text { щільна, } 3 \text { наявністю чи відсут- } \\
\text { ністю частинок наповнювача }\end{array}$ \\
\hline $\begin{array}{l}\text { Сиркові маси солодкі: } \\
\text { нежирна та напівжирна } \\
\text { солодка } 3 \text { кріопорош- } \\
\text { ком «Амарант» }\end{array}$ & $\begin{array}{l}\text { Світло-жовтий, світло- } \\
\text { коричневий однорідний }\end{array}$ & $\begin{array}{l}\text { Свіжий, солодкий, } \\
\text { кислуватий, чітко виражений } \\
\text { присмак і запах кріопорошку }\end{array}$ & $\begin{array}{l}\text { Мазеподібна, наявні окремі } \\
\text { вкраплення кріопорошку }\end{array}$ \\
\hline
\end{tabular}

Смак дослідних зразків був відповідно солодким із більш чітким присмаком біодобавки у солодких нежирних сиркових масах.

Ще однією важливою групою показників для характеристики сиркових мас є фізико-хімічні їх характеристики.

Фізико-хімічні методи аналізу відрізняються великою вибірковістю, чутливістю, швидкістю виконання аналітичних операцій. Фізико-хімічні методи аналізу дозволяють вести в промисловості безперервний кон- троль, автоматизувати процес аналізу. Як відомо, згідно з нормативними вимогами всі сиркові маси, що випускаються молокопереробною галуззю в Україні, повинні відповідати певним фізико-хімічним константам (для кисломолочного сиру та сиркових виробів це титрована кислотність; мч вологи та жиру, енергетична цінність).

Фізико-хімічні показники дослідних зразків солодких сиркових різної жирності 3 кріобіодобавкою наведені у відповідній таблиці.

Табличя 3

Основні фізико-хімічні показники сиркових мас із кріопорошком «Амарант»

\begin{tabular}{|c|c|c|c|c|c|}
\hline \multirow{2}{*}{ Назва сиркової маси } & \multirow{2}{*}{$\begin{array}{c}\text { Кислотність } \\
\left({ }^{\circ} \mathrm{T}\right)\end{array}$} & \multicolumn{3}{|c|}{ Масова частка } & \multirow{2}{*}{$\begin{array}{l}\text { Енергетична цінність } \\
\text { (ккал/100 г) }\end{array}$} \\
\hline & & волога & $\mathrm{CP}$ & жиру,\% & \\
\hline Нормативні величини сиркових мас & $120-200$ & $60-70$ & - & $\begin{array}{c}\text { н/ж } \\
4-6\end{array}$ & $120-180$ \\
\hline $\begin{array}{l}\text { Сиркові маси солодкі: нежирна та } \\
\text { напівжирна солодка } 3 \text { кріопорошком } \\
\text { «Амарант» }\end{array}$ & $146 / 148$ & $59 / 56$ & $41 / 44$ & $\begin{array}{c}\mathrm{H} / ж ; \\
4,6\end{array}$ & $154 / 168$ \\
\hline
\end{tabular}

Аналіз цифрового матеріалу таблиці 3 свідчить, що додавання кріобіодобавки певним чином впливає і на фізико-хімічні характеристики. Так, титрована кислотність дослідних зразків солодких нежирних сиркових мас складала $154^{\circ} \mathrm{T}$, мг вологи $59 \%$ і СР $41 \%$, а величини енергетичної цінності складали 154 ккал/100 г продукту.

Зміни фізико-хімічних характеристик напівжирних солодких напівжирних сиркових мас мали аналогічну амплітуду змін. Так, титрована кислотність дослідних зразків коливалась в межах $148{ }^{\circ} \mathrm{T}$; масова частка вологи складала $56 \%$; масова частка сухої речовини 44\%. Варто зауважити, що вміст жиру в напівжирних сиркових масах внаслідок додавання кріобіодобавки складав $4,6 \%$.

Як відомо, одним 3 найефективніших способів стимулювання споживчого попиту є дегустація, яка має всі підстави для «самостійного життя» того чи іншого молочного продукту. Дегустація - це вид стимулювання споживача чи виробника 3 метою ознайомлення цільової аудиторії зі смаком, властивостями товару, а також з метою ініціювання здійснення пробної купівлі. Покупець чи виробник може спробувати продукцію до того, як прийме рішення про іiі придбання. Особливо рекомендується проводити дегустації при виведенні на ринок нових торгівельних марок або при розширенні смакової лінії у рамках однієї торгівельної марки.

Такі дегустації і були проведені нами стосовно дослідних зразків нашої продукції. Дегустаційна оцінка дослідних зразків сиркових мас із кріопорошком «Амарант» констатувала в середньому 28 та 27 балів відповідно з 30 балів можливих, що свідчить про повну нормативну відповідальність та якісні товарознавчі характеристики.

Водночас слід констатувати, що внесення кріопорошку в сиркові маси різної жирності поряд з лікувально-профілактичною дією приводить не лише до підвищення енергетичної цінності. Отримані зміни в концентраціях вітамінів та у співвідношеннях амінокислот свідчать про підвищення біологічної цінності пропонованої продукції.

Таким чином, обгрунтовано доцільність використання кріопорошку «Амарант» в технології сиркових мас різної жирності та виду, що підвищує їх біологічну цінність та відповідає нормативним вимогам до 
даного виду продукції. Розробка захищена патентом України.

\section{Висновки}

1. Досліджено можливість застосування кріопорошку «Амарант», як складника лікувальнопрофілактичних сиркових мас.

2. Технологія сиркових мас із кріопорошком «Амарант» передбачає їх виробництво із цукром різної жирності.

3. Вивчено органолептичні, технологічні та товарознавчі характеристики даних сиркових мас із кріопорошком «Амарант».

4. Пропоновані сиркові маси із кріопорошком «Амарант» мали приємний товарний вигляд, нормативні фізико-хімічні характеристики.

\section{Бібліографічні посилання}

Natsionalnyi standart Ukrainy (2008). «Vyroby syrkovi», Zahalni tekhnichni umovy. DSTU 4503; 2005. Kyiv «Derzhspozhyvstandart Ukrainy» (in Ukrainian).
Hachak, Yu.R., Varyvoda, Yu.Iu., Slyvka, N.B. (2011). Molochni produkty likuvalno-profilaktychnoho pryznachennia. Posibnyk. Lviv (in Ukrainian).

Gutyj, B., Hachak, Y., Vavrysevych, J., Nagovska, V. (2017). The elaboration of cheese masses of therapeutic and prophylactic direction with cryoadditive «Pumpkin». «EUREKA: Life Sciences». 1, 19-26.

Gutyj, B., Hachak, Y., Vavrysevych, J ., Nagovska, V. (2017). The influence of cryopowder «Garbuz» on the technology of curds of different fat content. EasternEuropean Journal of Enterprise Technologies. 2, 10(86), 20-24.

Yatsenko, I.V., Bohatko, N.M., Bukalova, N.V., Fotina, T.I., Biben, I.A., Berhilevych, O.M., Hachak, Yu.R., Tkachuk, S.A., Kamianskyi, V.V. , Bondarevskyi, M.M., Zazharska, N.M., Tsyvirko, I.L., Kasianenko, O.M. (2016). Hihiiena moloka i molochnykh produktiv. Chastyna 2. Hihiiena molochnykh produktiv: Pidruchnyk. Kharkiv: «Dias plius» (in Ukrainian).

Inform-lystok «Krioporoshky» (2014). BBG «Blue Bird Group LTD (in Ukrainian). 